\title{
CD81 wt Allele
}

National Cancer Institute

\section{Source}

National Cancer Institute. CD81 wt Allele. NCI Thesaurus. Code C74512.

Human CD81 wild-type allele is located in the vicinity of 11 p15.5 and is approximately 20

$\mathrm{kb}$ in length. This allele, which encodes CD81 antigen protein, may be involved in the regulation of both signal transduction and Hepatitis C infectivity. 